\title{
Insecticidal effect of Fusarium subglutinans on Frankliniella occidentalis (Pergande) (Thysanoptera: Thripidae)
}

\author{
O. Demirözer*, A. Uzun, Ş.-E. Arici, I. Gep and R. Bakay
}

Summary Fusarium subglutinans (Ascomycota: Nectriaceae) is known to have lethal effects on aphid species, while there are limited studies associated with other arthropods. In this study, the effect of different spore concentrations $\left(1 \times 10^{4}, 1 \times 10^{6}\right.$ and $1 \times 10^{8}$ spores $\left./ \mathrm{ml}\right)$ of $F$. subglutinans $12 \mathrm{~A}$, isolated from $A p$ his gossypii in Adana-Karataş (Turkey), was investigated on Frankliniella occidentalis (Pergande) (Thysanoptera: Thripidae) females and on $2^{\text {nd }}$ instar nymphs (only $1 \times 10^{6} \mathrm{spores} / \mathrm{ml}$ ). The application method was by dipping and observations on mortality of females were conducted 24, 48, 72, 96 hours and 7 and 9 days after application. Mycosis was also observed on dead individulas. Mortality of nymphs was recorded during 8 days after application. Higher average dead females were found in the treatments compared to the control, but there was not significant difference between the tested concentrations (Mycosis rate recorded in $1 \times 10^{6}$ spores $/ \mathrm{ml}$ was higher than those in $1 \times 10^{4}$ and $1 \times 10^{8}$ spores $/ \mathrm{ml}$ ). The highest and lowest mycosis rates were observed on the $7^{\text {th }}$ and $3^{\text {rd }}$ day, respectively. Average number of dead $2^{\text {nd }}$ instar nymphs recorded in $1 \times 10^{6} \mathrm{spores} / \mathrm{ml}$ did not differ from control.

Additional keywords: Biological control, entomopathogenic fungi, pest, thrips

\section{Introduction}

The Western Flower Thrips (WFT) Frankliniella occidentalis (Pergande) (Thysanoptera: Thripidae) is a serious pest feeding on leaves, fruits and flowers and causing direct and indirect damages on agricultural crops and ornamental plants (Bryan and Smith, 1956; Miliczky and Horton, 2011; Demirözer et al., 2012). Due to significant number of thrips vectors for viral pathogens, they are known as destructive pests worldwide.

The WFT spread to the World from North-West of the United States (Kirk and Terry, 2002). The first presence of WFT in Turkey was recorded in vegetable fields of Antalya (Western Mediterranean region) in 1993 (Tunç and Göçmen, 1994) and in a very short time it suppressed the Frankliniella intonsa (Trybom) which was the main thrips species in cotton fields in Çukurova region (East Mediterranean) (Atakan et al., 1998; Atakan and Özgür, 1998; 2000; Atakan, 2003; Doğanlar and Aydin, 2009).

Süleyman Demirel University, Faculty of Agriculture, Department of Plant Protection 32260 Isparta-Turkey * Corresponding author: ozandemirozer@sdu.edu.tr
Short generation period, high reproductive capacity and thigmotactic behaviour of $F$. occidentalis are reasons that make it difficult to control. In addition, rapid resistance development ability against insecticides also contributes to the difficulty in the control of F. occidentalis. The WFT is known to be resistant to carbamates (bendiocarb, formetanate, methiocarb), organophosphates (diazinon), spinosyn (spinosad) and pyrethroids (acrinathrin, deltamethrin, fenvalerate, permethrin) (Jensen, 2000; Bielza, 2008; Cloyd, 2009).

Besides the difficulties in the suppression of thrips populations, chemical insecticides are known to have side effects on the natural enemies of the WFT (Goettel and Hajek, 2000; Pell et al., 2001; Jones et al., 2005; Demirözer et al., 2012). Since entomopathogens are specific to their hosts and they reproduce they are a desirable alternative in pest control (Charnley and Collins, 2007). Additionally, low risk on the non-target organisims supports safeuse of entomopathogens in control practices (Eilenberg et al., 2001; Augustyniuk-Kram \& Kram, 2012; Shadid et al., 2012).

There are 750 known species of entomopathogenic fungi, which belong to $85 \mathrm{ge}$ - 
nus of the Plyla Ascomycota and Zygomycota (Samson et al., 1988; McCoy et al., 1988; Gillespie and Moorhouse, 1989). A considerable number of these species belong to the genera Beauveria, Entomophthora, Metarhizium, Neozygites, Nomuraea and Lecanicillium (Desphande, 1999; Shadid et al., 2012). Although Fusarium spp. (Ascomycota: Nectriaceae) cause diseases in a number of economically important plants, the species Fusarium subglutinans isolated from aphids has entomopathogenic action on arthropods (Gerin, 1998; Erkiliç et al., 1999; Satar et al., 2000).

The aim of this study was to determine the insecticidal effect of three different spore concentrations $\left(1 \times 10^{4}, 1 \times 10^{6}\right.$ and $1 \times 10^{8}$ spores $/ \mathrm{ml}$ ) of $F$. subglutinans $12 \mathrm{~A}$ on adult females of $F$. occidentalis. The mycosis rate was recorded on dead individuals of the thrips. Additionally, the effect of $1 \times 10^{6}$ spores $/ \mathrm{ml}$ concentration was investigated on the $2^{\text {nd }}$ instar nymphs of F. occidentalis.

\section{Materials and Methods}

The study plant was pepper (Capsicum annuum). Adult females and $2^{\text {nd }}$ instar nymphs of F. occidentalis used in the experiments came from laboratory colonies kept at $25 \pm 1^{\circ} \mathrm{C}, 60$ $70 \% \mathrm{RH}$ and 16:8 h L:D. The isolate 12A of $F$. subglutinans from Aphis gossypii in AdanaKarataş, Turkey was used for making suspensions of the fungus.

In the study, spore concentrations of $1 \times 10^{4}, 1 \times 10^{6}$ and $1 \times 10^{8}$ spores $/ \mathrm{ml}$ were prepared by using suspension of $F$. subglutinans 12A; they were cultured on potato dextrose agar (PDA) and incubated at $25^{\circ} \mathrm{C}$ for 10 days. Spore concentrations were determined by using Thoma counting chamber. In the control, distilled water and Tween 20 $(0.1 \%)$ was used.

The experiment was conducted in glass Petri dishes ( $9 \mathrm{~cm}$ diameter) containing pepper leaf discs ( $5 \mathrm{~cm}$ diameter) on filter papers, to feed the thrips. In each treatment 10 individuals, newly emerged adult females or $2^{\text {nd }}$ instar nymphs, were used. Before the treat- ment, thrips were deprived food for 1 hour. The application method was by dipping for 5 seconds. After treatment the thrips were transferred by using a moisturized fine paint brush to the Petri dishes, which were then covered with parafilm to prevent their possible escape. The experimental design was a complete randomized block with five replications. The Petri dishes were kept in climate-controlled rooms at $25 \pm 1^{\circ} \mathrm{C}, 60-70 \%$ $\mathrm{RH}$, and 16:8 h D:L.

Observations on mortality were made at 24, 48, 72 and 96 hours, and 7 and 9 days after the dipping. Mycosis observations were performed between the third and ninth day of the study. Counting on the $2^{\text {nd }}$ instar nymphs was initiated 24 hours after the dipping and repeated every 24 hours until the $8^{\text {th }}$ day of the experiment. Re-isolation was made at the end of the counting process on dead individuals.

\section{Statistical Analysis}

Square root transformation was applied to the data of dead individuals. Inverse angle transformation was applied to the mycosis data obtained from dead flesh (body) of adults. Data were analysed using repeated measurement analysis of variance in a factorial design (treatment $x$ time). Linear relation between dead individuals and mycosis rates was investigated by calculating the Pearson correlation coefficient. The MannWhitney ' $U$ ' test was applied to the data obtained from $2^{\text {nd }}$ instar nymphs of F. occidentalis, since the data were non-parametric. Significance level was $\mathrm{P}<0.05$.

\section{Results}

The mean numbers of dead females of $F$. ocidentallis after dipping in solutions of three different spore concentrations of $F$. subglutinans $12 \mathrm{~A}$ are presented in Table 1. The control had the lowest mean number of dead females, which was significantly different from the other treatments $(P<0.05)$. The mean 
Table 1. Mean mortality of adult females of Frankliniella occidentalis and mycosis rate on dead individuals after treatment with three different spore concentrations of Fusarium subglutinans $12 \mathrm{~A}$.

\begin{tabular}{l|c|c}
\hline $\begin{array}{c}\text { Treatments } \\
\text { (spores/ml) }\end{array}$ & $\begin{array}{c}\text { Mortality } \\
\text { Mean } \pm \text { s.e. }\end{array}$ & $\begin{array}{c}\text { Mycosis rate } \\
\text { Mean } \pm \text { s.e. }\end{array}$ \\
\hline $10^{4}$ & $3.67 \pm 0.756 \mathrm{a}$ & $0.989 \pm 0.230 \mathrm{~b}$ \\
$10^{6}$ & $3.47 \pm 0.724 \mathrm{a}$ & $1.794 \pm 0.351 \mathrm{a}$ \\
$10^{8}$ & $4.20 \pm 0.732 \mathrm{a}$ & $1.455 \pm 0.262 \mathrm{ab}$ \\
Control & $0.70 \pm 0.180 \mathrm{~b}$ & \\
\hline
\end{tabular}

Means with different letter in the same column differ significantly $(P<0.05)$; s.e.: standard error

mortality obtained in three spore concentrations did not differ significantly between them $(P>0.05)$.

In the concentrations $10^{6}$ and $10^{8}$ spores/ $\mathrm{ml}$, first deaths of adults were observed 24 hours after dipping, whereas this was 48 hours in $10^{4}$ spores/ml (Figure 1). In the control, deaths were observed three days after dipping into the water and the mortality percentage was $16 \%$ on the $8^{\text {th }}$ day of the experiment. Mortality percentage was $100 \%$ in the three spore concentrations of F. subglutinans $12 \mathrm{~A}$ on the $9^{\text {th }}$ day of the experiment
(Figure 1).

The highest mycosis rate was recorded in $10^{6}$ spores $/ \mathrm{ml}(1.794 \pm 0.351)$ and was higher than the average mycosis rates of $10^{8}$ and $10^{4}$ spores/ml concentrations ( $\mathrm{P}<0.05$; Table 1$)$. The Pearson correlation coefficient between the death and mycosis rates was 0.68 and it was found significant $(P<0.01)$. In addition, a linear relationship was determined between the death and mycosis rates and mycosis became visible three days after the application (Table 1). The highest mycosis rates were observed on the 7th and 9th day after application and the lowest rate was recorded three days after application in all spore concentrations. The Pearson correlation coefficient between the time and mycosis rate was 0.93 and it was significant $(P<0.01)$.

Deaths of $2^{\text {nd }}$ instar nymphs at $10^{6}$ spores/ $\mathrm{ml}$ concentration of the fungus were observed starting on the second day of spore applications. The results showed that percentage of mortality was more than $50 \%$ on the $8^{\text {th }}$ day of the study (Figure 2). The ' $R$ ' value of average dead individuals was 0.412 and it was different from the control $(P<0.01)$.

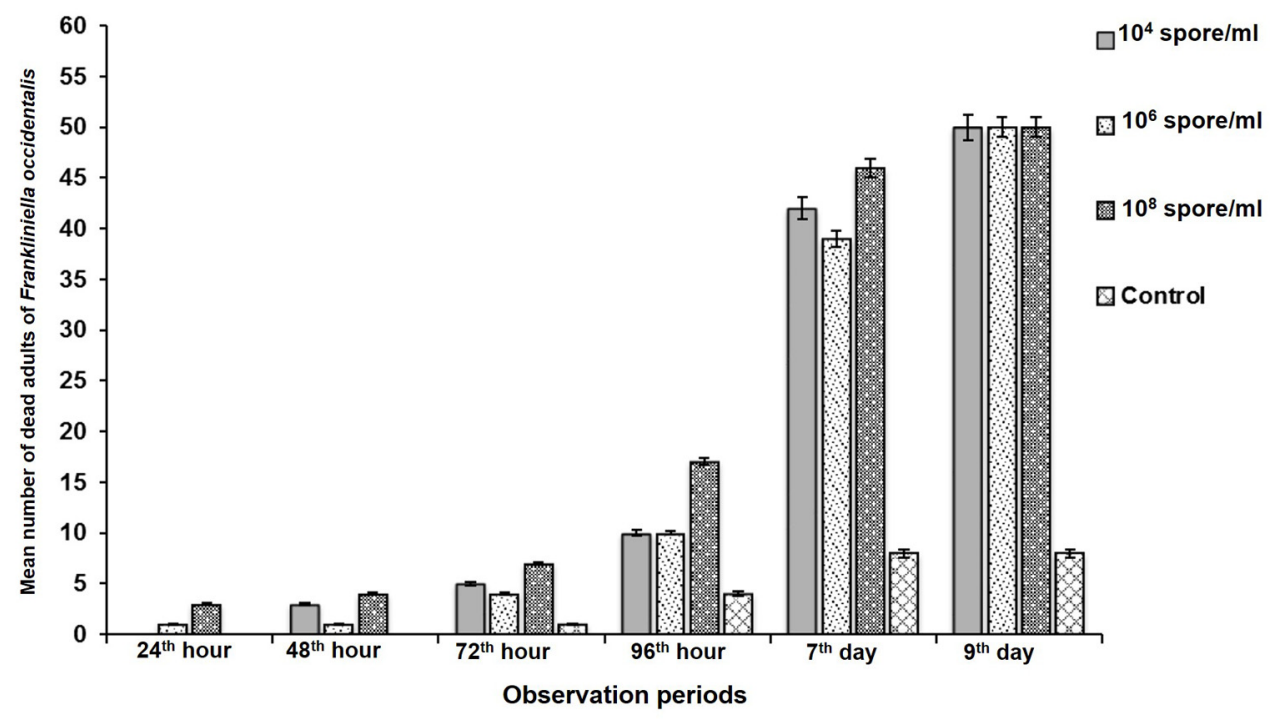

Figure 1. Mean number of dead adult females of Frankliniella occidentalis after treatment (dipping) with three different spore concentrations of Fusarium subglutinans. 


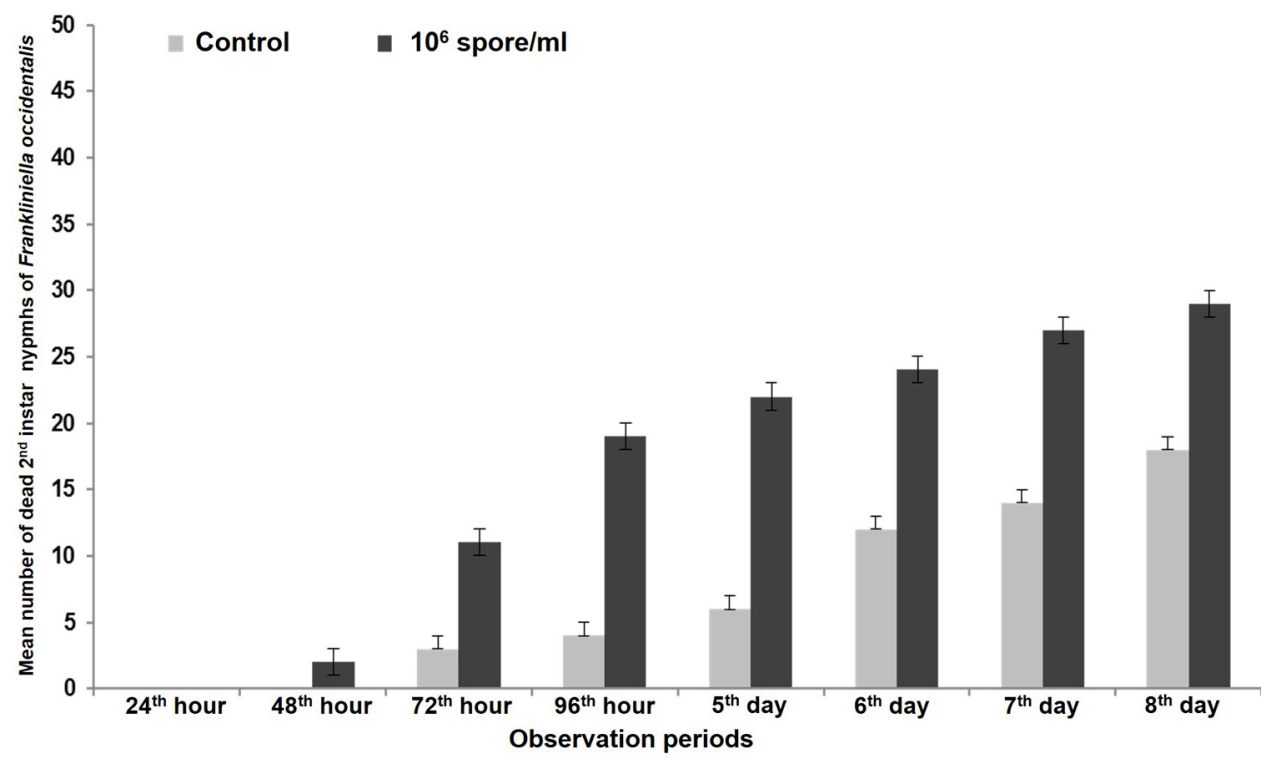

Figure 2. Mean number of $2^{\text {nd }}$ instar nymphs of Frankliniella occidentalis after treatment (dipping) with $1 \times 10^{6} \mathrm{spores} / \mathrm{ml}$ concentration of Fusarium subglutinans $12 \mathrm{~A}$.

\section{Discussion}

Previous studies focused on efficacy of $F$. subglutinans on several aphid species (Erkiliç et al., 1999; Satar et al., 2000; Satar and Koç, 2004; Arici et al., 2012). Satar et al. (2000) reported that $1 \times 10^{7}$ spores $/ \mathrm{ml}$ concentration of F. subglutinans caused $16 \%$ and $45.5 \%$ deaths on A. gossypii (Hemiptera: Aphididae) which fed on cotton and eggplant, respectively, and $12.9 \%$ on Myzus persicae (Hemiptera: Aphididae) which fed on eggplant.

In the present study, $1 \times 10^{4}-1 \times 10^{8}$ spores/ $\mathrm{ml}$ concentrations of $F$. subglutinans $12 \mathrm{~A}$ had similar efficacy (in terms of mortality) against the thrips $F$. occidentallis but the $1 \times 10^{6}$ spores $/ \mathrm{ml}$ concentration was found appropriate for mycosis. Lethal effect of $F$. subglutinans could be expected to vary on different host plants, pest species and different life stages of pests. The mortality rate of the $10^{6} \mathrm{spores} / \mathrm{ml}$ concentration of $F$. subglutinans $12 \mathrm{~A}$ was $58 \%$ on the $2^{\text {nd }}$ instar nymphs of the thrips. The concentration $10^{6}$ spores/ $\mathrm{ml}$ of $F$. subglutinans was the most effective on A. gossypii and $A$. fabae in studies by Satar and Koç (2004) and; Arici et al. (2012).

Other fungi recorded to have biocidal effect on F. occidentalis include Beauveria bassiana, Lecanicillium (Verticilium) lecanii (Ascomycota: Cordycipitaceae) and Metarhizium anisopliae (Clavicipitaceae) (Jacobson et al., 2001; Ludwig and Oetting, 2002; Maniania et al., 2002). Whereas recorded mortality rates were $20-70 \%$ for L. lecanii, these were $93.5-100 \%$ for $M$. anisopliae on different life stages of $F$. occidentalis (Vestergaard et al., 1995; Gouli et al., 2009). Several efficacy studies of different spore concentrations of $B$. bassiana showed that this fungus caused $67-96 \%$ deaths on pre adult stages of $F$. occidentalis. In addition $1 \times 10^{7}$ conidia/ml was the most effective spore concentration in several other studies Gouli et al., 2009; Gao et al., 2012; Wu et al., 2014), However these studies have no data on mycosis rates of the pest.

In conclusion, F. subglutinans $12 \mathrm{~A}$ had a lethal effect on $F$. occidentalis and the fungus was found more effective on adults than the $2^{\text {nd }}$ instar nymphs. Developing hyphae and spores of entomopathogenic fungi provide 
infection to other individulas in the pest population (Moutia, 1936; Shahid et al., 2012). Present study results suggest that three days are required for mycosis to become visible from the application and seven days later mycosis rate reaches the highest level. Based on the results obtained from this study it is recommended future studies to focus on $F$. subglutinans 12A mode of action on arthropods, infection features and side effects of this fungus on natural enemies.

Authors thank Prof. Dr Hayati Köknaroğlu (Süleyman Demirel University, Faculty of Agriculture, Animal Science Department, Turkey) for language assistance to the study. This research was funded by TUBITAK 2209-A program.

\section{Literature Cited}

Arici, Ş.E, Gülmez, I., Demirekin, H., Zahmekiran, H. and Karaca, i. 2012. Entomopatojen Fusarium subglutinans'in bakla yaprakbiti, Aphis fabae Scopoli (Hemiptera: Aphididae) üzerine etkisi. Türkiye Biyolojik Mücadele Dergisi, 3(1): 89-96.

Atakan, E. 2003. Frankliniella occidentalis (Pergande) (Thysanoptera; Thripidae)'nin pamuk bitkisinde zararinin araştirilmasi. Türkiye Entomoloji Dergisi, 27(1): 39- 49.

Atakan, E. and Özgür, A.F. 1998. Çukurova'da pamukta çiçek tripsleri Frankliniella intonsa (Trybom), F. occidentalis (Pergande) (Thysanoptera; Thripidae) üzerine Notlar. Çukurova Üniversitesi Ziraat Fakültesi Dergisi, 13(1): 174-184.

Atakan, E. and Özgür, A.F. 2000. Çukurova yöresi pamuk alanlarinda görülen Frankliniella intonsa (Trybom), F. occidentalis (Pergande) (Thysanoptera; Thripidae)'nin popülasyon değişimleri. Türkiye 4. Entomoloji Kongresi, Aydin, Türkiye, 12-15 Eylül, 2000, p. 53-61.

Atakan, E., Özgür, A.F., Kersting, U. 1998. Frankliniella occidentalis (Pergande) (Thysanoptera, Thripidae) on cotton in Çukurova Region. In Proceedings Sixth International Symposium on Thysanoptera, Antalya, Turkey, April 27-May 1, 1998, p. 7-12.

Augustyniuk-Kram, A. and Kram, K.J. 2012. Entomopathogenic Fungi as an Important Natural Regulator of Insect Outbreaks in Forests. In: BLANCO, J.A. et. al. (eds.). Forest Ecosystems-More than just Trees. Rijeka: InTech, p. 265-294.

Bielza, P. 2008. Insecticide resistance management strategies against the western flower thrips, Frankliniella occidentalis. Pest Management Sci- ence, 64: 1131-1138.

Bryan, D.E. and Smith, R.F. 1956. The Frankliniella occidentalis (Pergande) complex in California (Thysanoptera: Thripidae). University of California Publication Entry. 10: 359-410.

Charnley, A.K. and Collins, S.A. 2007. Entomopathogenic Fungi and Their Role in Pest Control. In: Kubicek, C.P. et. al. (eds.), The Mycota. Berlin Heidelberg: Springer, p. 159-187.

Cloyd, R.A. 2009. Western flower thrips (Frankliniella occidentalis) management on ornamental crops grown in greenhouses: Have we reached an impass? Pest Technology, 3(1): 1-9.

Demirözer, O., Arici, Ş.E., Sevinç, M.S. and Karaca, ì. 2010. Fusarium subglutinans'in Chilocorus nigritus (Fabricius) (Coleoptera: Coccinellidae) üzerindeki patolojik etkisinin belirlenmesine yönelik ön çalişma. Türkiye Biyolojik Mücadele Dergisi, 1(2): 151-155.

Demirözer, O., Tyler-Julian, K., Funderburk, J., Leppla, N.and Reitz, S. 2012. Frankliniella occidentalis (Pergande) integrated pest management programs for fruiting vegetables in Florida. Pest Management Science, 68: 1537-1545.

Deshpande, M.V. 1999. Mycopesticide production by fermentation: Potential and challenges. Critical Reviews in Microbiology, 25: 229-243.

Doğanlar, M. and Aydin, S. 2009. Güneydoğu Anadolu Bölgesi (Türkiye)'nde yeni bir zararlı, Frankliniella occidentalis (Pergande) (Thysanoptera: Thripidae). Türkiye Entomoloji Dergisi, 33(2): 153160.

Eilenberg, J., Hajek, A. and Lomer, C. 2001. Suggestion for unifying the terminology in biological control. BioControl, 46(4): 387-400.

Erkiliç, L., Pala, H., Başpınar, N. and Biçer, Y. 1999. Doğu Akdeniz Bölgesi'nde bazi yaprakbiti türlerinde entomopatojen funguslarin belirlenmesi. Türkiye 4. Biyolojik Mücadele Kongresi, Adana, Türkiye, 26-29 Ocak, 1999, p. 623-632.

Gao, Y., Lei, Z. and Reitz, S.R. 2012. Western flower thrips resistance to insecticides: detection, mechanisms and management strategies. Pest Management Science, 68: 1111-1121.

Gerin, Y. 1998. Yaprakbiti Aphis gosypii Glover (Homoptera: Aphididae) ile Fusarium subglutinans (Wollenw \& Reiking) Nelson, Tousson \& Mararsa Arasindaki Konukçu Patojen ílişkisi. Adana: Çukurova Üniversitesi, 50 p. Yüksek Lisans Tezi.

Gillespie, A.T. and Moorhouse, E.R. 1989. The Use of Fungi to Control Pest of Agricultural and Horticultural Importance, In: Whipps, J.M. et. al. (eds). Biotechnology of Fungi for Improvement of Plant Growth. London: Cambridge University Press, p. 55-84.

Goettel, M.S. and Hajek, A.E. 2000. Evaluation of Non-target Effects of Pathogens Used for Management of Arthropods, In: Wajnberg, E. et. al. (eds). Evaluating Indirect Ecological Effects of Bi- 
ological Control. Wallingford: CABI Publishing, p. 81-97.

Gouli, S., Gouli, V., Skinner, M., Parker, B., Marcelino, J. and Shternshis, M. 2008. Mortality of western flower thrips, Frankliniella occidentalis, under influence of single and mixed fungal inoculations. Journal of Agricultural Technology, 4(2): 37-47.

Gouli, V.V., Gouli, S.Y., Skinner, M. and Shternshis, M.V. 2009. Effect of the entomopathogenic fungi on mortality and injury level of western flower thrips, Frankliniella occidentalis. Archives of Phytopathology and Plant Protection, 42(2): 118123.

Jacobson, R.J., Chandler, D., Fenlon, J. and Russell, K.M. 2001. Compatibility of Beauveria bassiana (Balsamo) Vuillemin with Amblyseius cucumeris Oudemans (Acarina: Phytoseiidae) to control Frankliniella occidentalis Pergande (Thysanoptera: Thripidae) on cucumber plants. Biocontrol Science and Technology, 11: 391-400.

Jensen, S.E. 2000. Insecticide resistance in the Western Flower Thrips, Frankliniella occidentalis. Integrated Pest Management Reviews, 5(2): 131-146.

Jones, T., Scott-Dupree, C., Harris, R., Shipp, L. and Harris, B. 2005. The efficacy of spinosad against the western flower thrips, Frankliniella occidentalis, and its impact on associated biological control agents on greenhouse cucumbers in southern Ontario. Pest Management Science, 61 (2):179-185.

Kirk, D.J.W. and Terry, L.I. 2002. The spread of the western flower thrips Frankliniella occidentalis (Pergande). Agricultural and Forest Entomology, 5: 301-310.

Ludwig, S.W. and Oetting, R.D. 2002. Efficacy of Beauveria bassiana plus insect attractants for enhanced control of Frankliniella occidentalis (Thysanoptera: Thripidae). Florida Entomological Society, 85 (1): 270-272.

Maniania, N.K., Ekesi, S., Löhr, B. and Mwangi, F. 2002. Prospects for biological control of the western flower thrips, Frankliniella occidentalis, with the entomopathogenic fungus, Metarhizium anisopliae, on chrysanthemum. Kluwer Academic Publishers Netherland, 155: 229-235.

McCoy, C.W., Samson, R.A. and Boucias, D.G. 1988. Entomogenous Fungi. In: IGNOFFO, C.M. et. al. (eds). Handbook of Natural Pesticides: Microorganisms. CRCPress, p. 260.

Miliczky, E. and Horton, D.R. 2011. Occurrence of the Western Flower Thrips, Frankliniella occidentalis, and potential predators on host plants in nearorchard habitats of Washington and Oregon (Thysanoptera: Thripidae). Journal of the Entomological Society of British Columbia, 108: 11-28.

Moutia, L.A. 1936. The sugar cane white grub Lachnosterna (Phytalus) smithi Arrow in Mauritius.
Proceedings International Society of Sugar Cane Technologists. 5: 436-445.

Pell, J.K., Eilenberg, J., Hajek, A.E. and Steinkraus, D.C. 2001. Biology, Ecology and Pest Management Potential of Entomophthorales, In: Butt, T.M. et. al. (eds). Fungi as Biocontrol Agents: Progress, Problems and Potential. Wallingford: $C A B$ International, p. 71-153.

Samson, R.A., Evans, H.C. and Latg, J.P. 1988. Atlas of Entomopathogenic Fungi. Berlin Heidelberg: Springer. p. 187.

Satar, S., Biçer Gerin, Y. and Bakircioğlu Erkiliç, L. 2000. Entomopatojen fungus Fusarium subglutinans'in laboratuvar koşullarinda bazi yaprakbiti türleri üzerindeki etkileri. Türkiye 4. Entomoloji Kongresi, Aydın, Türkiye, 12-1 5 Eylül, p. 317-322.

Satar, H. and Koç, N.M. 2004. Entomopatojen fungus Fusarium subglutinans'ın Aphis gossypii Glover'ye karşi biyolojik etkinliğinin belirlenmesi. Türkiye 6. Biyolojik Mücadele Kongresi. Samsun, Türkiye, 8-10 Eylül, 2004, p. 89.

Shahid, A.A., Rao, A.Q., Bakhsh, A. and Tayyab, H. 2012. Entomopathogenic fungi as biological controllers: new insights into their virulence and pathogenicity. Archives of Biological Sciences, 64(1): 21-42.

Şevik, M.A. 2008. Thrips (Thripidae: Thysanoptera) türleri ile taşınan bitki virüsleri. Derim, 25(1): $1-11$.

Tunç, İ. and Göçmen, H. 1994. New greenhouse pests, Polyphagatarsonemus latus and Frankliniella occidentalis in Turkey. FAO Plant Protection Bulletin, 42(3): 218-220.

Whitfield, A.E., Ullman, D.E. and German, T.L. 2005. Tospovirus-thrips interactions. Annual Review Phytopathology, 43: 459-489.

Wu, S., Gao, Y., Zhang, Y., Wang, E., Xu, X. and Lei, Z. 2014. An entomopathogenic strain of Beauveria bassiana against Frankliniella occidentalis with no detrimental effect on the predatory mite $\mathrm{Ne}$ oseiulus barkeri: evidence from laboratory bioassay and scanning electron microscopic observation. Plos One, 9(1): 1-7.

Vestergaard, S., Gillespie, A.T., Butt, T.M., Schreiter, G. and Eilenberg, J. 1995. Pathogenicity of the Hyphomycete Fungi Verticillium lecanii and Metarhizium anisopliae to the Western Flower Thrips, Frankliniella occidentalis. Biocontrol Science and Technology, 5: 185-192.

Received: 7 January 2016; Accepted: 15 May 2016 


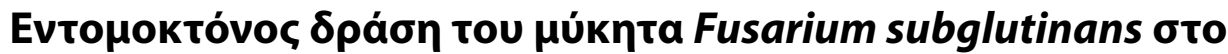

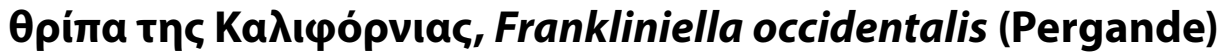 (Thysanoptera: Thripidae)
}

\author{
O. Demirözer, A. Uzun, Ş.-E. Arici, İ. Gep and R. Bakay
}

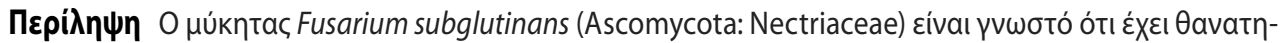

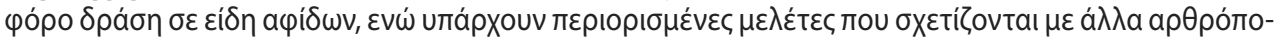

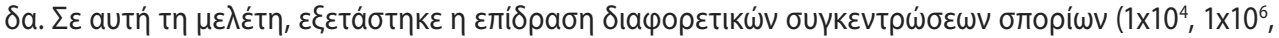

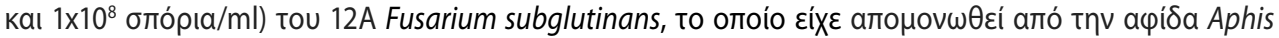
gossypii бта Adana-Karataş (Тоuркі́a), бто Өрі́та Frankliniella occidentalis (Pergande) (Thysanoptera:

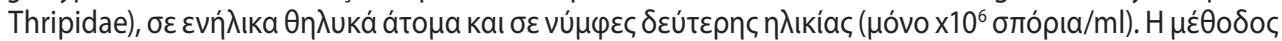

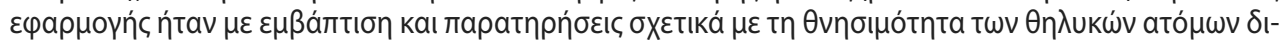

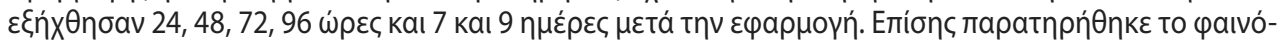

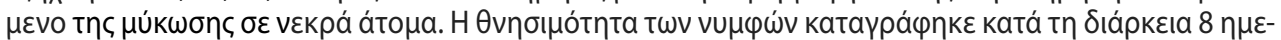

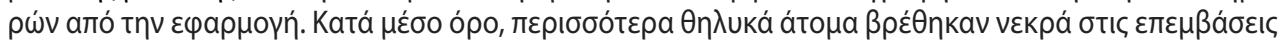

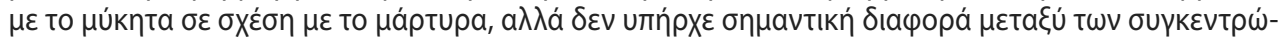

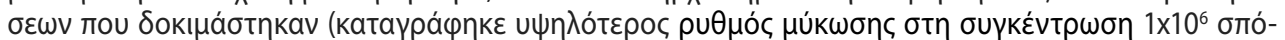

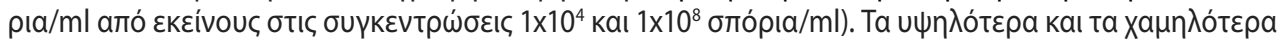

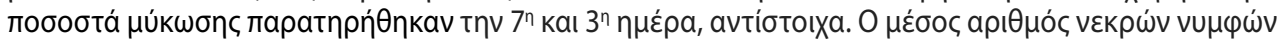

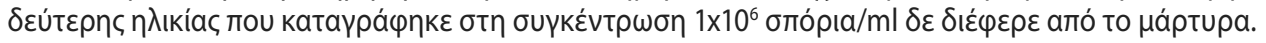

